\title{
ATTITUDE OF EMPLOYEES TOWARDS CHANGE INITIATIVES AS INFLUENCED BY COMMITMENT AND JOB SATISFACTION: THE CASE OF SELECTED HIGHER EDUCATION INSTITUTIONS IN ETHIOPIA
}

\author{
Megersa Wedajo Motuma ${ }^{1}$, Belay Chekole ${ }^{2}$ \\ ${ }^{1,2}$ College of Business and Economics, Jimma University, Jimma, Ethiopia \\ megersa_wo@yahoo.com, belayche76@gmail.com
}

\section{Original Scientific Paper 10.5937/jouproman8-25868}

\begin{abstract}
This study aimed at examining the influence of organizational commitment and job satisfaction on attitudes of employees toward change initiatives in public universities in Ethiopia. SelfAdministered questionnaires were prepared and distributed to 200 randomly selected teachers in selected universities via e-mail addresses. Correlation and Regression analysis was made to see the influences of the two variables. The findings revealed that employees' general attitudes towards change initiatives is influenced by Job satisfaction $(\mathrm{p}<0.05)$. However, it did not indicate a significant influence of employee's commitment to their organization on attitudes of employees regarding change initiatives $(\mathrm{p}>0.05)$.
\end{abstract}

Keywords: Change Initiatives, Attitude towards change, organizational commitment, Job satisfaction, Higher Education Institutions

\section{INTRODUCTION}

Change happens to be a customary event in organizations because of the quick general public and economic changes. Organizational change is a set of diverse measures that results in changing directions and/or processes that have an effect on the manner in which organizations work previously (Hage, 1999). Organizational change in Public sector is usually termed as reform. Pollitt and Bouckaert (2004) described public management reform as "deliberate changes to the structures and processes of public sector organizations with the objective of getting them to run better."

Due to the new challenges in improving quality of education, higher education institutes in Ethiopia are under pressure to restructure and reform (Daryush, Mehran \& Heydar, 2008). In order to make these efforts fruitful, different change initiatives (e.g. Active learning, Modularization, Change Army, Kaizen) and performance management tools like Balanced Scorecard are being implemented in higher education institutions.

However, prior study has generally recognized that considerable number of organizational change initiatives neither brought about their planned objectives nor advance persistent change due to an execution failure (Kotter, 1995, as cited in Choi 2011). Research suggests that the failure of organizational change initiatives can generally be attributed to negative employee attitudes towards the change during implementation process (Bellou 2007; Coetsee 1999; Durmaz 2007 as cited in Visagie \& Steyn, 2011). Studies have also indicated the failure during change implementation attempt due to undervaluing of the crucial position of individuals in the change practices (Armenakis, George \& Jones, 2001; Choi, 2011). In order to make a change happen in various organizational contexts, in higher education in particular, individuals must change. This is because individuals, i.e., employees as the target of change, their perceptions, expertise, drives and basic understanding form a considerable element of the workplaces where changes are going to take place (Smith, 2005 as cited in Alfonsus, 2008). 
In this regard, beside change initiative implementation attempt, identification of employees' attitude toward change initiatives and conditions that indicate employees' support for organizational change are very important. Studies have demonstrated various antecedents to particular organizational change programs (Deloitte \& Touche, 1996 as cited in Vakola and Nikolaou, 2005). The basic reason of failure in change program is due to unconstructive perception of employees of change itself. As part of public reform evaluation, a study has been conducted by Civil Service Transformation Research Center in 2012. It has indicated a limited success mainly because of the attitudes of people in general and the civil servant in particular. As it is less exhaustive in nature, this study did not indicate the reason why the attitudes ' of people toward those change initiatives is negative.

Research scholars had confirmed challenges in executing and leading organizational change endeavors usually result in organizational catastrophes (Probst \& Raisch, 2005). Because of this, great consideration has been given to investigating the determinant that increases the probability of effectively realizing organizational change endeavors. Studies on organizational change have examined attitude toward change in connection to stage of commitment and job satisfaction under different public organizations context (Roderick, 1996; Alireza, 2014; Alfonsus, 2008; Vakola and Nikolaou, 2005; Muhammad, et al, 2010; Daniel, 2009). Committed Employees voluntarily exert more energy in change initiatives and, leading to a higher likelihood of developing constructive attitudes towards change (Iverson, 1996). In addition to commitment, level of job satisfaction has been considered the most important factor that influences employees' acceptance of organizational change. According to Spector (1997) as cited in Muhammad, et al. (2010), employees stay or leave their organization depending on how much they are satisfied with their job.

However, limited studies have examined those variables in public higher education setting in Ethiopia. Thus, by framing our inquiry into organizational management perspective, the aims of this research are to evaluate employees` attitude toward change initiatives and to investigate the effect of organization commitment and job satisfaction in shaping the attitudes of employees in selected Public universities.

\subsection{Study Objectives}

The objectives of this study are:

- To investigate the influence of organizational commitment on employees`attitude towards change initiatives.

- To investigate the effect of job satisfaction influence on employees attitude towards organizational change initiatives.

\section{REVIEW OF RELATED LITERATURE}

\subsection{Theoretical Review}

\subsubsection{Definition of change}

Kanter (1992) described change as:

"The crystallization of new possibilities (new policies, new behaviors, new patterns, new methodologies, new products or new market ideas) based on the reconceptualised patterns in the institution".

\subsubsection{Attitudes organizational change \\ toward}

Elias (2009) defined Attitudes toward organizational change as "an employee's overall positive or negative evaluative judgment of a change initiative implemented by their organization." 
Though change is a common agenda for today's modern organizations, its success can be affected by different factors. According to Damanpour (1991), leaders' outlook to change governs worker involvement and the successful advancement of programmes of change. Furthermore, another cause for the lack of success in majority of change initiatives are people`s struggle against change (Bovey \& Hede, 2001). This information alone rationalizes the examination of individual's cognitive development as an element of organizational change (Zimmerman, 2006).

\subsubsection{The relationship of attitude towards organizational change and commitment organizational}

In his study Iverson (1996) revealed that employee getting into a change process is grown by organizational commitment.

Lau and Woodman (1995) demonstrated that a well dedicated individual is more agreeable to acknowledge organizational change when it seems to be advantageous. However, studies have also shown that a well devoted employees may refuse to accept change if they perceive the change as a threat to their personal gain. These indicate the possibility of organizational commitment effect on attitudes to organizational change initiatives. Furthermore, employees committed to their organizations are more likely to voluntarily engage in a change processes and, consequently, there is a high likelihood of developing positive attitudes (Iverson, 1996).

\subsubsection{Job satisfaction and Attitudes towards organizational change}

Locke (1976) defined Job satisfaction as "the extent to which an employee feels positively or negatively toward his/her jobs."

Many Researchers have identified the association of job satisfaction and attitudes to change. Yousef (2000a) confirmed that a positive perception of change in general rose with the boost of satisfaction due to compensation. There is more acceptance of change if employees are satisfied with diverse aspects of their job and absence of extrinsic job satisfaction were linked with poor attitudes toward change (Darwish, 1999).

\subsection{Empirical Review}

This study is aimed at examining the influence of organizational commitment and job satisfaction on general attitudes of employees towards change initiatives. To achieve these purposes, we critically reviewed some related empirical studies hereunder. Carlo (2012) has conducted a study to identify how employees perceived the change process affects them. The findings indicated that employees were not pleased with the change course of actions being executed. The study also presented the solutions suggested by employee including introduction of the urgency and requirement of the change in straightforward terms; set up a change leadership management team consists of truthful workforces with good technical and interpersonal relationships skills; with managerial position; and best strategies. Study conducted by Kleanthis (2014) and his friends explored the perceptions of employee about suitability of change at the time of intended change under hospital setting. The results indicated a considerable raise in attitudes of employees towards aptness of change once the deliberate change realization. This result also indicated that variations in the above attitudes are moderated by job satisfaction.

\subsection{Conceptual frame-work}

Despite positive contributions, the studies reviewed above have some limitations. First, the inconsistencies of the findings with regard to which factors affect employee attitudes and the role of leaders during implementation of change. 
Second, regarding the effect of employees commitment and job satisfaction on employees' attitude studies were very limited. Moreover, almost all studies were conducted out of higher education setting. Therefore, the current study filled the gap in literature by examining the attitude of employees toward change initiatives in general, and the role commitment and jobs satisfaction playing in shaping the attitudes using the following conceptual framework.

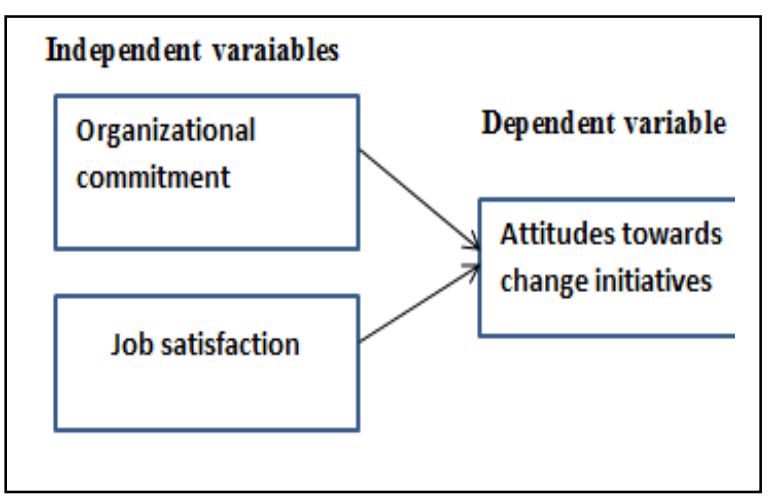

Figure 1. Conceptual framework the research

\section{METHODS}

\subsection{Target population}

The target population for this research was employees who were engaged in teaching duties at least for one year in three public universities.

\subsection{Sampling frame, sampling method and sample size}

From those three Universities, 200 employees were randomly selected from the lists of about 3000 academic workers. Data was collectedand with self-administered questionnaires. About 121 questionnaires were returned resulting in $60 \%$ response rate. The number of samples were determined based on the guideline proposed by Carvalho (1984). He proposed 200 samples for the study population in the range of 1201-3200 people.

\subsection{Instrument development and data collection}

Three self-administered instruments were distributed to collect cross-sectional data. Online survey was sent to participants`email through Google form. Respondents were requested to show the degree to which they agree with every statement (Item) on a five point Likert scale. The average of the items was used for further analysis.

Attitude towards Change (ATC): Attitude towards change was measured with instrument of attitude toward change developed by RANDALL, et al. (1989). ATC measures employees' attitude in relation to recent organizational change initiatives. The scale consists of 18 items that are measured using a five point Likert scale ranging from strongly disagree (1) to strongly agree (5) and reversed if the item is stated negatively.

Organizational Commitment (OC): To measure OC, nine general commitment scales were adopted from the threeComponent Model of Meyer and Natalie (2004). The scales were measured using a five point Likert scale ranging from strongly disagree (1) to strongly agree (5) and reversed if the item is stated negatively.

Job Satisfaction (JS): Three items were taken from Michigan organizational assessment package. These items are measured using a Likert scale categorized as highly dissatisfied to highly satisfied.

\subsection{Model Specification}

Since the purposes of the study is to identify if two independents variables (i.e.organizational commitment and job satisfaction) shape dependent variable (i.e. general attitude of employees towards change).So to create the linear relationship between the dependent and independent variables, Multiple Linear regression model were used as follows. 
$\mathrm{Yi}=\beta 0+\beta \mathrm{iXi}+\mathrm{ei}$

Where,

$\mathrm{Yi}=\mathrm{is}$ the value of the dependent scale variable.

$\beta 0=$ the intercept of regression equation

$\beta i=$ the coefficient of each independent variables

$\mathrm{Xi}=$ the values of the predictors

ei=the error term

Hence, it follows,

$\mathrm{ATC}=\beta 0+\beta 1 \mathrm{OC}+\beta 2 \mathrm{JS}(2)$

Where,

$\beta 0=$ The value when the value of predictor is

equal to 0 .

$\beta 1,2=$ the coefficient of OC \&JS

ATC $=$ Employees`attitude towards change (dependent variable)

$\mathrm{OC}=$ Organizational commitment

(independent variable)

JS=Job Satisfaction (independent variable)

\subsection{Data Analysis}

Descriptive Analysis was performed using the average of Attitudes towards Change scale to determine if the attitude is favourable or unfavourable towards change. Pearson's correlation coefficient between all variables were examined to specify the strength of correlations. In order to identify the effect of independent variables on dependent variable, multiple linear regressions were be used.

\subsection{Reliability test}

In order to identify strict internal consistency of scales, Cranach's coefficient was calculated (table I). Cranach's coefficient in all cases was over 0.7 with employees` attitudes scale (0.806), employees' commitment scale (0.764) and Job satisfaction scale (0.810). Since the acceptable limits of Cronbach's alpha according to Nunnally \&Bernstein (1994) ranges from 0.60 to 0.80 , the items are considered reliable.

\section{RESULT AND DISCUSSION}

\subsection{Data Description}

To give few descriptions about the data based on mean and standard deviation, Table I is constructed for the variables. The mean and std. deviation of Attitude towards change is 3.48, the highest mean of all 0.329 respectively. The next highest mean is 2.865 for organizational commitment with 0.348 std. deviation. The lowest mean recorded was for job satisfaction (i.e. 2.929) with std. deviation of 0.424 .

TABLE I. DESCRIPTIVE STATISTICS OF THE VARIABLES

\begin{tabular}{llll}
\hline \multicolumn{1}{c}{ Variables } & Mean & Std. Deviation & N \\
Attitude towards & 3.488 & 0.329 & 121 \\
change & & & \\
commitment & 2.865 & 0.348 & 121 \\
Job satisfaction & 2.929 & 0.424 & 121 \\
Valid N (list wise) & & & 121 \\
\hline
\end{tabular}

4.2.The Influence of Commitment and Job satisfaction on Employees attitude towards change

To see if employees` level of organizational Commitment and Job satisfaction have a role in shaping attitudes towards change, linear regression analysis was conducted.
Meanwhile, the second research question of this study is answered. Under this topic, statistics that are related to Linear Regression will be discussed. 


\subsubsection{Correlation analysis}

Correlation analysis was made to establish the association among the variables of the study. Pearson Correlation coefficient was used for this purpose. As seen in Table II, employees attitude towards change and job satisfaction are significantly related $(\mathrm{r}=0.457 ; \mathrm{p}<0.05) \quad$ while statistically insignificant relationships have been found between employees attitudes towards change and commitment ( $\mathrm{r}=0.051) ; \mathrm{p}>0.05)$.

Table II. Correlations

\begin{tabular}{lllll}
\hline & & $\begin{array}{l}\text { attitude } \\
\text { toward change }\end{array}$ & commitment & Job satisfaction \\
Pearson & Attitude towards change & 1.000 & & \\
Correlation & commitment & 0.051 & 1.000 & 1.000 \\
& Job satisfaction & 0.457 & -0.109 & 0.024 \\
Sig. (1-tailed) & Attitude towards change & & 0.418 & 0.328 \\
& commitment & 0.418 & & \\
& Job satisfaction & $0.024^{*}$ & 0.328 & \\
\hline
\end{tabular}

\subsubsection{Regression analysis}

Multiple linear regression analysis was run to identify if two variables, organizational commitment and job satisfaction affect the current employees' attitude and to model this relationship. Before starting regression analysis, collinearity, was tested. As depicted in table III, collinearity diagnostics were made using Tolerance and Variance inflation factor. Tolerance values that are close to zero and below are showing the possibility of multi-collinearity of the variables.

Table III. Multi-collinearity test

\begin{tabular}{lll}
\hline & Collinearity Statistics & \\
& Tolerance & VIF \\
commitment & 0.988 & 1.012 \\
Job satisfaction & 0.988 & 1.012 \\
\hline
\end{tabular}

With respect to Tolerance, the values are not close to zero. Regarding the VIF standards if the value is greater than two, the possibility of multi-collinearity would be evident. The Lower values implied that the predictors are free of multi-collinearity issues.

Table IV.Regression Coefficients ${ }^{\mathrm{a}}$
Table IV shows the coefficients of the regression line. As it can be seen, the expected Attitude scale value, equal to $2.145+0.097$ Commitment value+ $0.364 \mathrm{Jobs}$ satisfaction values.

\begin{tabular}{llllll}
\hline $\begin{array}{l}\text { Model } \\
1\end{array}$ & Unstand. Coeff. & & & \\
& B & Std. Error & Stand. & t & Sig. \\
Coeff. & & 2.584 & 0.020 \\
Constant) & 2.145 & 0.830 & & 0.461 & 0.651 \\
commitment & 0.097 & 0.210 & 0.102 & 2.109 & 0.045 \\
\hline Job satisfaction & 0.364 & 0.173 & 0.469 & & \\
\hline
\end{tabular}

a. Dependent variable: attitude towards change 
This implies that a unit variation in commitment value causes 0.097 times increase in variation of attitudes values and the value of attitude to change varies by 0.364 times the unit variation of job satisfaction value. This entails that the unit variations of the predictors cause very little variation in employees attitude scale.

Table IV shows also the significance levels of coefficients. Even though not strong, the significant value of T-test for Job satisfaction $(\mathrm{P}<0.05)$ shows the contribution of Job satisfaction which is substantial in employees` attitude variation. The implication is that the increase in employees' Job satisfaction to their organization increases their attitudes towards change initiatives and vice-versa. This finding is in agreement with Lau and Woodman (1995) who argued that high satisfaction level of employee on the job they were engaged can enables to predict the acceptance of organizational change. Similar to this, Darwish (1999) demonstrated the association between lower stages of extrinsic job satisfaction and negative attitudes toward change. Cordery et al. (1993) and Gardner et al. (1987) reported the same result that they observed significance interaction between satisfaction and change. Thus, to bring effective change, employees' job satisfaction must be assessed initially.

Table V. ANOVA ${ }^{\mathrm{ab}}$
Further, the insignificant test result is the indication that organizational commitment variable does not contribute much to the model. The implication is that any variation in employee's job commitment does not result in positive/negative attitudes of employees regarding change initiatives. This finding is inconsistent with the findings of Iverson (1996) and Guest (1987) who argued that highly committed employees to their organization are most likely develop favorable attitudes for change. Iverson (1996) found that employees who are highly attached to their organization most probably accept organizational change. Regarding the significance of commitment, Lau and Woodman (1995) confirmed that the more commitment, the more willingness to shoulder organizational change when it is believed to be beneficial. This finding is inconsistent also with the findings of Iverson (1996). He put commitment as a dominant contributing factor of attitudes towards change next to union membership

To check the model fit or its acceptability, analysis of variance was run (table $\mathrm{V}$ ). The $\mathrm{F}$ statistic shown in the table revealed that the variation explained by the model is due to significant variation in at least one predictor variable not by chance.

\begin{tabular}{|c|c|c|c|c|c|c|}
\hline \\
\hline \multirow{5}{*}{$\begin{array}{l}\text { Mode } \\
1\end{array}$} & & $\begin{array}{l}\text { Sum of } \\
\text { Squares }\end{array}$ & & Mean & & \\
\hline & & & $\mathrm{df}$ & Square & $\mathrm{F}$ & Sig. \\
\hline & Regression & 1.738 & 2 & 0.869 & 4.950 & $0.009^{\mathrm{a}}$ \\
\hline & Residual & 19.492 & 118 & 0.176 & Residual & 19.492 \\
\hline & Total & 21.230 & 120 & & & \\
\hline
\end{tabular}

a. Predictors: (Constant), Job satisfaction, Commitment

b. Dependent Variable: Attitude towards Change 
Analysis of variance also shows the variations that are explained and that are not explained by the model. In the table above, regression sums of square, 1.738 shows the variation accounted for by the model, which is by far less than residual sums of square,19.492. This implied that little variation in employees' attitude towards change is due to variation in independent variables. This means variables other than commitment and job satisfaction might have large contribution. According to Shah (2011), employee attitudes could be affected by other socioeconomic and cultural variables. In addition, Yosef (2011) demonstrated that civil service reforms were impeded by lack of structural set up that is amenable to reforms execution, lack of proper control, absence of clearly defined management system and procedure of effective and efficient utilization of human resource and lack of managerial know how.

\section{CONCLUSION}

The major purposes of this study were to provide empirical support on the employees` general attitude towards change initiatives as influenced by commitment and job satisfaction. In the surveyed Higher education institutions, the following conclusions were made based the findings.

We found out employees' attitude towards change initiatives and employees' job satisfaction was found to be significantly related, while no relationship exists between organization commitment and employees' attitude. This means that any variation in employee's commitment does not result in positive or negative attitudes of employees regarding change initiatives. Moreover, the contribution of Job satisfaction for current employees`attitude found to be substantial which leads to the conclusion that the variation in job satisfaction scale will cause the variation in employees' attitude scale.

\section{Future Research Direction}

Like any other study, the present one also comes with some limitations. Like any other study, this is also with some limitations. The second is related to the focuses of this study to mandatory changes. Many scholars demonstrated that attitude towards change is a good predictor of future behavior (Ajzen \& Fishbein, $1980)$ if it is a non-mandatory change. Scholars argued that the more mandatory the change is the more an attitude towards change could not predict real change behavior (Kijsanayotin et al., 2009).The other limitation is its focuses to general attitudes towards change not to specific change. It is recommended that real behavior is more correctly predicted by distinctive attitudes than general attitude (Choi, 2011). A third limitation is related to target population of this study. To get the full picture of challenges and employees attitude towards change, both academic and administration would have been more appropriate. In this study however, the latter staffs were used as a target population to avoid the variation. Hence, we put suggestions for future research that both mandatory and voluntary changes; both general attitudes towards change and specific change be studied by using both academic and administrative of higher education to get some comprehensive findings in the area.

\section{BIBLIOGRAPHY}

Ajzen, I., \& Fishbein, M. (1980). Understanding attitudes and predicting behavior. Englewood Cliffs, NJ: Prentice-Hall.

Alfonsus, B. S. (2008). Organizational Readiness for Change: A Case Study on Change Readiness in a Manufacturing Company in Indonesia: International journal of management perspectives.

Alireza, Z. (2014.) Job Satisfaction and Organizational Justice as Predictors of Attitude Concerning Organizational Reform (Unpublished Thesis). Lunds University. 
Avidov-Ungar, O., \& Eshet-Alkakay, Y. (2011). Teachers in a world of change: Teachers' knowledge and attitudes towards the implementation of innovative technologies in schools. Interdisciplinary Journal of E-Learning and Learning Objects (IJELLO),

Beer, M., Eisenstat, R.A., and Spector, B. (1990) .Why Change Programs Don't Produce Change. Harvard Business Review, (Nov.-Dec.), 158-166.

Bellou, V. (2007). 'Psychological contract assessment after a major organizational change: The case of mergers and acquisitions', Employee Relations, 29(1): 68-88.

Bovey, W. \& Hede, A. (2001). 'Resistance to organizational change: The role of cognitive and affective processes'. Leadership and Organizational Development Journal, 22(1): 372-382.

Boyne, A. (2003). Evaluating Public Management Reforms. London: Open University Press.

Blackmore, A. (2005). The Reform of Public Services: The Role of the Voluntary Sector. London: NCVO

Blackman, D., O’Flynn, J. and Ugyel, L. (2013) “A Diagnostic Tool for Assessing Organizational Readiness for Complex Change", paper presented to the Australian and New Zealand Academy of Management conference, Hobart, 4-6 December.

Carvalho, J. (1984). Archival application of mathematical sampling techniques. Records Management Quarterly, 18, 60-63.

Carlo, D. (2012). Understanding change and change management processes (a case study): $\mathrm{PhD}$ Dissertation (unpublished).University of Canberra.

Chane, P. (2001). The challenges of the civil service Reform in Ethiopia: Initial Observations.EASSRR,Vol.XVII.no.1.

Choi, Myungweon. (2011). Employees' attitudes towards organizational change: A literature review. Human Resource Management, 50(4), 479-500.

Coetsee, L. 1999. 'From resistance to commitment', Public Administration Quarterly, 23, 204-222.

Cole, M. S., Bruch, H., \& Vogel, B. (2006). Emotion as mediators of the relations between perceived supervisor support and psychological hardiness on employee cynicism. Journal of Organizational Behavior, 27, 463-484.
Cordery, J., Sevastos, P., Mueller, W., \& Parker, S. (1993). Correlates of employee attitude toward functional flexibility. Human Relations, 46(6), 70523.

Damanpour, F. (1991). Organizational innovation: a meta-analysis of effects of determinants and moderators. Academy of Management Journal. 34 (3), 555-590.

Darwish, A. Y. (1999). Organizational commitment and job satisfaction as predictors of attitudes toward organizational change in a nonwestern setting. Personal Review 29,5.

Darwish, A. Y. (2017) Organizational Commitment, Job Satisfaction and Attitudes toward Organizational Change: A Study in the Local Government, International Journal of Public Administration, 40:1, 77-88

Daryush, F., Mehran, N. and Heydar, M. (2008). Balanced scorecard application in universities and higher education institutes: Implementation guide in an Iranian context / Annals of University of Bucharest, Economic and Administrative Series, Nr. 2 (2008) 31-4

David, G. (n.d). Attitude towards Organizational Change among Public Middle. Public Personnel Management. University of Lausanne Institute of political and international studies Géopolis, Switzerland.

David, J. (1967). Manual for Minnesota satisfaction questionnaire (Unpublished).University of Minnesota.

Dumond, E. (1994). Making Best Use of Performance Measures and Information. International Journal of Operational and production Management, 14 (35), 16-31.

Durmaz, H. (2007). Officer attitudes toward organizational change in the Turkish national police. Unpublished doctoral thesis, University of North Texas, Texas.

Elias, S. (2009). Employee Commitment in times of Change: Assessing the Importance of Attitudes towards Organizational Change. Journal of Management, 35(1), 37-55.

Guest, D. (1992). Employee commitment and control. In Hartley, J.F. and Stephenson, G.M. (Eds.). Employment Relations, Blackwell, Oxford. 
Hair et al., (2006) argued that correlation coefficient below 0.90 may not cause serious multicollinearity problem.

Hirve, K. \&. Sekar . (2007). Risk Factors and Barriers to Process Reengineering. Hood, C. and M. Jackson. (199). Administrative Argument. Aldershot: Dartmouth.

Iverson, R. D. (1996). Employee acceptance of organizational change: The role of organizational commitment. The International Journal of Human Resource Management, 7, 122-149

Josie, K. (2007). Reforming public services in the UK: Bringing in the third sector. Public administration 85, (4).

John, P. Meyer and Natalie J. Allen (2004). TCM Employee Commitment Survey. Academic Users Guide (unpublished). The University of Western Ontario.

Johnson, J. (2002), .11th September 2001: Will It Make a Difference to the Global Anti-Money Laundering Movement? Journal of Money Laundering Control, 6(1), 9.

Kanter, R.M. (1983). The change masters: Innovation for productivity in the American corporation. New York: Simon and Schuster in Tanzania, from 1991-2000: University of Bergen, Norway.

Kieffer, T. (2005), Feeling Bad: Antecedents and Consequences of Negative Emotions in ongoing Change, Journal of Organizational Behavior, 26, 875-897.

Kijsanayotin, B. Pannarunothai, S., \& Speedie, S. M. (2009). Factors influencing health information technology adoption in Thailand's community health centers: Applying the UTAUT model. International Journal of Medical Informatics, 78, 404-416.

Kleanthis, K., K., Athanasios, N. T. and SofiaMaria, N. B. (2014).Exploring employees perceptions, job-related attitudes and characteristics during a planned organizational change. Int. Journal of Business Science and Applied Management, 9 (1).

Kotter, J.P. (1996), Leading Change, Boston: Harvard Business School Press.

Lau, C., \& Woodman, R. C. (1995). Understanding organizational change: a schematic perspective. Academy of Management Journal, 38(2), 537-54.
Locke, E. A. (1976). The nature and causes of job satisfaction. In M. D. Dunnette (Ed.), Handbook of industrial and organizational psychology ( 1297 1349). New York, NY: Hold, Reinhart \& Winston.

Lukumai Emmanuel, C., (2006). The Implementation of Civil Service Reforms.

Lycke, L. (2003). Team development when implementing TPM.Total Quality Management, 14(2), 205-213.

McCourt, W. (2013). Models of Public Service Reform: A Problem Solving Approach. Policy Research Working Paper, No. 6428. Washington D.C: The World Bank.

MdG, (2011). Best Practices in Civil Service Reform: Reference and Resource Manual Public Sector Reform. MDGD, n.d. civil service reform Paper http://unpan1.un.org/intradoc/groups/public/docum ents/un/unpan001183.pdfv

Miller, V. D., Johnson, J. R., \&Grau, J. (1994). Antecedents to willingness to participate in a planned organizational change. Journal of Applied Communication Research, 22(1), 59-80.

Ministry of Civil Service (MOSC). (2011).The direction of Reform Army Building in the Civil Service: Unpublished document of Ministry of Civil Service (Prepared in Amharic)

Ministry of Civil Service.(2014). Federal Civil Service Change Army Development Manual. Ethiopia, Addis Ababa.

Moran, J. W. and Brightman, B. K. (2001) 'Leading organizational change', Career Development International, 6(2), 111-118.

Muhammad, M., Samina, N., Basharat N.\& Rizwan, D. (2010). Job Satisfaction and Organizational Commitment of University Teachers in Public Sector of Pakistan. International Journal of Business and Management, 5 (6).

Naimatullah, S, (2011),"A study of the relationship between organizational justice and employee readiness for change", Journal of Enterprise Information Management, 24(3), 224 - 236.

Newhouse, David R. and Chapman, Ian D. (1996), .Organizational Transformation: A Case Study of Two Aboriginal Organizations., Human Relations, 49(7), 995-1011.

Neves, P., \& Caetano, A. (2009). Commitment to change: Contributions to trust in the supervisor 
and work outcomes. Group \& Organization Management, 34(6), 623-644.

Orit, A. \&Yoram, E. (2011). Teachers in a World of Change: Teachers' Knowledge and Attitudes towards the Implementation of Innovative Technologies in Schools. Interdisciplinary Journal of E-Learning and Learning Objects Volume 7.

O'Roark, A. M. (2007). Guidelines for education and training at the doctoral and postdoctoral levels in consulting psychology/organizational consulting psychology. American Psychological Association.

Parish, J. T., Cadwallader, S., \& Busch, P. (2008). Want to, need to, ought to: Employee commitment to organizational change. Journal of Organizational Change Management, 21(1), 32-52.

Pollitt, C. \& Bouckaert, G.(2004). Public Management reform. A comparative analysis. Oxford university press.

Probst, G., \&Raisch, S. (2005). Organizational crisis: The logic of failure. Academy of Management Review, 19(1), 90-105.

Rao, S. (2013). Civil Service Reform: Topic Guide, Birmingham, UK: Governance and Social Development Resource Centre (GSDRC), University of Birmingham.

Roderick , D. I. (1996). Employee acceptance of organizational change: the role of organizational commitment. The International Journal of Human Resource Management 7.

Somekh, B. \& Lewin C. (2005). Research Methods in Social Sciences.Sage Publications. London: Thosusand Oaks.

Stephen, M. (2010). Change, technology and higher education: are Universities capable of organizational change. Journal of asynchronous learning networks, 15(4).

Tilaye Kassahun, (2007). Civil Service Reform in Ethiopia: Achievements, Problems and Possible
Solutions. Proceedings of the First National Conference on the Achievements, Challenges and Prospects of the Civil Service Reform Program Implementation in Ethiopia. Addis Ababa, Ethiopia.

Tilaye, K. (2007). Civil Service Reform in Ethiopia: Achievements, Problems and Possible Solutions. Proceedings of the First National Conference on the Achievements, Challenges and Prospects of the civil service reform program implementation in Ethiopia. Addis Ababa, Ethiopia.

Tryggvi, H. (2008). Organizational change and change readiness: Employees' attitudes during times of proposed merger (unpublished), Universitetet i Troms $\emptyset$.

Visagie C. M \& Steyn C. (2011). Organizational commitment and responses to planned organizational change: An exploratory study. Southern African Business Review 15(3).

Vakola, M., \& Nikolaou, I. (2005). Attitudes towards organizational change: What is the role of employees' stress and commitment? Employee Relations, 27(2).

Visagie, C.M \& Steyn, C. (2011). Organizational commitment and responses to planned organizational change: An exploratory study. Southern African Business Review 15, (3).

Vakola, M., Tsaousis, I., \& Nikolaou, I. (2004). The role of emotional intelligence and personality variables on attitudes toward organizational change.

Yousef, D. A. (2000). Organizational commitment and job satisfaction as predictors of attitudes toward organizational change in a non-western setting. Personnel Review, 29, 567-592.

Yosef, T. (2011).Study of the Civil Service Reform in Adama City Administration: Regional state of Oromia- Ethiopia. A.A: A.A.U. 